\section{KILN SEASONING VENEERS FOR PLYWOOD MANUFACTURE}

$\mathrm{D}^{\mathrm{c}}$ URING the War considerable investigation and research work has been carried out at the Forest Research Institute, Dehra Dun, India, on the subject of plywood manufacture. Kiln seasoning has been studied. Two Indian Forest Leaflets, Nos. 57 and 61 (published by the Forest Research Institute, Dehra Dun), deal with "Furnace Heated Veneer Drying Kiln" and "Kiln Drying Schedule for Seasoning of Veneers", giving the latest practical information on these sübjects. In Leaflet No. 57, after directing attention to the necessity of the thorough seasoning of veneers before gluing and manufacture into plywood, it is pointed out that green veneers can be air-seasoned or kiln-dried, exactly like ordinary wood. The usual method in Europe and America for the quick seasoning of veneers is to dry them in Iong progressive dryers. This well-known type of dryer is very expensive, the pre-war price being more than 50,000 rupees.

Apart from the considerable price, it was found that this dryer was not essential for the quick seasoning of veneer, especially for the cheaper forms of plywood in so great demand in India, and that cheaper forms of timber seasoning kilns could be used. Experiments in this direction were undertaken and resulted in the furnace-heated veneer-drying kiln described. This is an indirect-heated internal-fan furnace kiln, suitable for the rapid seasoning of veneers before manufacture into plywood. It has been primarily designed for the use of plywood factories in which there is no provision for the supply of steam. The kiln has plenty of heating surface to raise the temperature of the circulating air in a short time. It is provided with four fans for the rapid circulation of air necessary for successful veneer drying. Provision is made for exhausting the moist air of the kiln through chimneys in the roof and for drawing in fresh air through the fresh-air ducts. The kiln is also provided with tracks and trucks, the latter of which are loaded with the green veneers outside and then pushed along the tracks into the drying chamber. It is estimated that $1 / 16 \mathrm{in}$. thick veneers of mango take about three hours for complete season. ing, as compared with a few minutes in the costly long progressive dryers of Europe and America. The cost of installation of the one described is estimated at about 5,000 rupees, at July 1943 current prices.

In,Leaflet No. 61 the results of experiments carried out on the kiln seasoning of veneers of mango (Mangifera indica), salai (Boswellia serrata), narikel (Sterculia alata) and sissoo (Dalbergia sissoo) are briefly described. From the results obtained for the first three of the above species, a kiln-drying schedule for the seasoning of veneers of light hardwoods, commonly used for cheap plywood, is recommended. A short description of different kinds of veneer dryers is also included.

\section{RESEARCHES IN PLANT VIRUS DISEASES}

CEVERAL workers at the Rothamsted Experi$\$$ mental Station have recently added to our know. ledge of plant virus diseases. A. Kleczkowski (Bio. chem. $J .,(2), 38,160 ; 1944)$ has found that tobacco mosaic virus does not combine with pepsin until it has been denatured by heat. Potato virus $X$, however, is a substrate for the proteolytic activity of pepsin, and combines with it. The same virus, is also a substrate for trypsin, which nevertheless combines more with tobacco mosaic virus, which is not a substrate. This action can explain the reversible inhibition of tobacco mosaic virus by trypsin. Invertase does not combine with either virus.

F. C. Bawden and N. W. Pirie have found (Brit. $J$. Exp. Path., 25, 68 ; 1944) that extracts of milled fibre from tomato plants infected with bushy stunt contain some virus combined with chromoprotein to form a non-precipitating antigen. The extracts would, however, precipitate with antiserum when the chromoprotein had been removed. Extracts from healthy plants to which pure virus is added are also non-precipitating.

B. Kassanis (Brit. J. Exp. Path., 24, 152; 1943) has studied the mechanism of neutralization of infectivity of several viruses by antisera. Unspecific neutralization by normal and heterologous sera is great in proportion to the additional specific effect of homologous antisera. Specific neutralization could only be used to demonstrate serological relationships if sera were of the same age and subjected to comparable storage conditions. Neutralization is not caused by precipitating antibodies, and precipitin titre is not correlated with neutralizing power. Specific antisera. for the sugar beet yellows virus have been prepared by A. Kleczkowski and M. A. Watson (Ann. Appl. Biol., 31, 2 ; 1944). The virus is not affected between $p \mathrm{H} 5$ and 9 , though it is relatively unstable. It has not yet been purified, though it is reversibly precipitated by ammonium sulphate, and sedimented. by high-speed centrifugation. The precipitin reaction with antisera can be applied to the crude sap, and is useful for diagnosis. Several workers have claimed that virus inactivation by formaldehyde and mercuric chloride is reversible, but B. Kassanis and A. Kleczkowski (Biochem. J., 38, 20; 1944) have not found this to be so with purified tobacco mosaic virus. Inactivation could be arrested at any stage by dilution or dialysis, but could not be reversed. Loss of infectivity caused by formaldehyde does not seem to depend on changes in amino-nitrogen groups.

Serological reactions and the production of intra. cellular inclusions have been used by F. C. Bawden and F. M. L. Sheffield (Ann. Appl. Biol., 31, 33; 1944) to establish relationships between viruses causing necrotic diseases of the potato. Potato virus $B$, and some others not previously described, are strains of virus $X$, and potato virus $C$ is a strain of virus $Y$. Virus $A$ is not related to $Y$ or $X$.

\section{FORTHCOMING EVENTS}

(Meeting marked with an asterisk * is open to the public)

Saturday, February 24

NUTRIIION SocIETy (at the London School of Hygiene and Tropical Medicine, Keppel Street, Gower Street, London, W.C.1), at 11 a.m.Discussion on "Factors Affecting the Nutritive Value of Bread as uman Food".

BRITISH PSychologicat SocikTy (in Room 134, Tuke Building. Bedford College for Women, Regent's Park, London, N.W.1), at 2.15 p.m.- "Training Industrial Workers" (a) Pearl H. M. King : "Some Suggestions for the Development of Personality through Industry"; (b) Helen Turner : "Proficiency, and Skill on the Job". at 4.30 p.m. $\rightarrow$ P. M. Freeston : "Children's Conceptions of Adult Life"; at 5.15 p.m. Madeline Kerr: "The Functions of Visual Imagery in the Formation of Stereotypes".

Association for Solfintific Photography (at Caxton Hall, Westminster, London, S.W.1), at 2.30 p.m.-Mr. D. R. Barber and Mr. E. H. Amstein: "Factors Influencing the Choice of Photographic Materials for Use in Quantitative Spectrography". 